\title{
Effect of type of diet and energy intake on milk production of Holstein-Friesian cows with extended lactations
}

\author{
C. Grainger, ${ }^{* 1}$ M. J. Auldist, ${ }^{* 2}$ G. O’Brien, ${ }^{*}$ K. L. Macmillan, $\dagger$ and C. Culley \\ ${ }^{*}$ Department of Primary Industries, Ellinbank 3821, Victoria, Australia \\ †Department of Veterinary Science, University of Melbourne, Werribee, Victoria 3030, Australia \\ ‡Keenan Pty. Ltd., 1/109 Breen Street, Bendigo 3550, Australia
}

\section{ABSTRACT}

The aim of this study was to measure the effect of type of diet and level of energy intake on the performance of cows undergoing extended lactations. Ninety-six Holstein-Friesian cows that calved in July and August 2004 were assigned randomly to 1 of 8 groups each of 12 cows (including 4 primiparous cows). Two of the 8 groups were assigned to each of 4 treatments that varied in lactation length $(300$ or $670 \mathrm{~d})$ and $\operatorname{diet}(3$ diets: control, high, or full total mixed ration (TMR). The 4 treatments were 1) control 300: cows were managed for a 300-d lactation and grazed pasture supplemented with grain and forage to provide a minimum daily dietary intake of $160 \mathrm{MJ}$ of ME/cow; 2) control 670: as for control 300 except that cows were managed for a 670-d lactation; 3) high 670: cows were managed for a 670-d lactation and pasture was supplemented with grain and forage to provide a minimum daily dietary intake of $180 \mathrm{MJ}$ of $\mathrm{ME} / \mathrm{cow}$; 4) full TMR 670: cows were managed for a TMR system that included a high body condition score at calving with cows offered a TMR during a 670-d lactation. The TMR was initially offered ad libitum indoors until about 440 DIM when the amount of TMR offered was reduced by about $2 \mathrm{~kg}$ of $\mathrm{DM} / \mathrm{d}$ to prevent excessive weight gain. The proportions of cows still milking at the end of a 670-d lactation were similar for the control and high dietary groups. The full TMR group had fewer cows milking at 600 DIM: 17 cows milking compared with 24 cows in the control 670 group and 22 cows in the high 670 group. For the period 1 to 670 DIM, increasing the energy level in the diet (control 670 vs. high 670) resulted in a similar yield of milk and a similar fat concentration in the milk, but greater yields of milk fat and protein and greater milk protein percentage of the milk. The full TMR 670 group produced greater yields of milk and

Received July 6, 2008.

Accepted November 14, 2008.

${ }^{1}$ Corresponding author: chris.grainger@dpi.vic.gov.au

${ }^{2}$ Current address: Fishing Monthly Group, PO Box 621, Queensland 4007, Australia. milk components (fat, protein, and lactose) and also protein percentage in the milk than the other groups. The milk solids (fat + protein) ratio for the 3 extendedlactation groups, defined as production achieved during the 24-mo calving interval divided by 2 yr (annualized production) expressed as a ratio of that produced in the normal 12-mo calving interval, was not affected by increasing the level of grain in the pasture-based diets (0.93 vs. 0.90 for control and high diets, respectively), but decreased with the TMR diet (0.79). The control 670 group produced $7.1 \%$ less milk, but only $2.4 \%$ less milk solids than the control 300 group over the 2-yr period of the study. Combining our data with that from 2 earlier studies of extended lactation demonstrated that Holstein cows with a high proportion of Northern Hemisphere genes offered pasture-based diets could achieve a high milk solids ratio, a greater proportion of cows milking at drying-off, and lower body weight gain over the lactation.

Key words: dairy cow, extended lactation, pasture and grain diet, total mixed ration

\section{INTRODUCTION}

Annual seasonally concentrated calving systems have traditionally been used in pasture-based dairying in the states of Victoria and Tasmania in Australia, and in New Zealand and Ireland (Dillon, 1996; Borman et al., 2004). These systems result in high utilization of pasture and low cost of production. More recently, there has been interest in extended lactation systems in both intensive dairying (van Amburgh et al., 1997; Osterman and Bertilsson, 2003) and pasture-based systems (Auldist et al., 2007; Kolver et al., 2008).

The dairy industry in Victoria has moved from seasonal to biseasonal calving systems (Dairy Australia, 2006). There has been a rapid change from most herds (63\%) having a seasonally concentrated calving pattern in 2004 to $41 \%$ in 2006. This decline involved herds with biseasonal calving patterns increasing from 33 to $50 \%$. The 3 main reasons given in a survey of farmers for the move to biseasonal calving were herd own- 
ers taking advantage of higher milk prices in winter, problems associated with herd reproduction, and an improvement in monthly cash flow (Dairy Australia, 2006). The Australian dairy industry has also increased its use of imported semen from Holstein sires since 1970 and the lower reproductive performance of the Holstein strain is well recognized (Lucy, 2001).

The key knowledge gaps identified in relation to extended lactation in a computer-assisted telephone survey of 250 dairy farmers in the 3 dairying regions of Victoria in 2003, were economics, persistence of lactation under feed management systems used in Victoria, and the influence of level of nutrition on performance of cows with extended lactations (O'Brien and Cole, 2004). Economic analyses of extended lactation systems have shown that they can be at least as profitable as seasonal calving systems (Malcolm, 2005; Trapnell and Malcolm, 2006). Two recent studies using pasture-based diets have shown that milking cows for 2-yr lactations is feasible and the penalty in annual milk solids production is small (Auldist et al., 2007; Kolver et al., 2008).

Kolver et al. (2008) examined the effect of strain (New Zealand or North American Holstein) and level of nutrition $(0,3$, or $6 \mathrm{~kg} / \mathrm{d}$ of concentrate $\mathrm{DM})$ on lactation performance up to $650 \mathrm{~d}$ and concluded that the 2 genotypes represented were able to be milked on pasture-based diets for productive 2-yr lactations.

The present study provides additional information on the effect of nutrition on extended-lactation performance. The primary objective was to measure the effects of type of diet (pasture-based or TMR system) and level of energy intake on a pasture-based diet on the milk production of cows with extended lactations. The TMR diet is used in Australia to a limited extent, but it was specifically included so that we could measure the potential to maximize performance of cows in extended lactation when nutrition was not limiting. A secondary objective was, for cows receiving a low level of nutrition using a pasture-based diet, to compare the milk production of cows that calved twice in a $2-y r$ period with cows that calved only once.

\section{MATERIALS AND METHODS}

\section{Cows and Design}

Ninety-six Holstein cows that calved in July and August 2004 were selected from the experimental herd at the Department of Primary Industries (DPI; Ellinbank, Victoria, Australia; latitude $38^{\circ} 14^{\prime} \mathrm{S}$, longitude $145^{\circ} 56^{\prime}$ E). Using the method described by Baird (1994), cows were assigned randomly to 1 of 8 groups each of 12 cows (including 4 primiparous cows) approximately
4 wk before the start of calving, balanced for parity, expected calving date, BW, and yields of milk, protein, and fat in the preceding lactation (excepting primiparous cows).

Two of the 8 groups were assigned to each of 4 treatments that varied in lactation length (300 or $670 \mathrm{~d})$ and diet (3 diets: control, high, or full TMR). The 4 treatments were 1) control 300: cows were managed for a 300-d lactation. Replicates $(\mathrm{n}=2)$ grazed pasture as separate groups and were supplemented with grain and forage to provide a minimum daily dietary intake of $160 \mathrm{MJ}$ of ME/cow; 2) control 670: cows were managed for a $670-d$ lactation. Replicates $(n=2)$ grazed pasture as separate groups and were supplemented with grain and forage to provide a minimum daily dietary intake of $160 \mathrm{MJ}$ of ME/cow; 3) high 670: cows were managed for a $670-d$ lactation. Replicates $(n=2)$ grazed pasture as separate groups and were supplemented with grain and forage to provide a minimum daily dietary intake of $180 \mathrm{MJ}$ of ME/cow; and 4) full TMR 670: cows were managed for a $670-d$ lactation. Replicates $(\mathrm{n}=2)$ were managed using a TMR system that included a higher average BCS at calving than the treatment groups on pasture-based diets, and a TMR diet during lactation. The higher BCS at calving for this group was in anticipation of higher expected BCS losses in early lactation because of greater anticipated milk production compared with the pasture-based diets. The premise behind this treatment was to maximize the performance of cows undergoing extended lactation when nutrition was not limiting under a TMR system.

Australian Breeding Values were calculated for the 96 cows (mean $\pm \mathrm{SD}$ ) using pedigree information based on the cow sire, cow maternal grand sire, and cow maternal great grand sire and were $9 \pm 432 \mathrm{~L}$ of milk (range: $-1,254$ to $916 \mathrm{~L}$ ), $1 \pm 11 \mathrm{~kg}$ of protein (range: -23 to $34 \mathrm{~kg}$ ), and $8 \pm 13 \mathrm{~kg}$ of fat (range: -22 to $39 \mathrm{~kg}$ ). The influence of Holstein-Friesian Northern Hemisphere genetics (i.e., United States, Canada, Netherlands, Germany, and Italy) was $64 \pm 13 \%$.

The experiment was conducted in accordance with the Australian Code of Practice for the Care and Use of Animals for Scientific Purposes (www.nhmrc.gov.au).

\section{Control Herd}

The 300-d lactation treatment acted as a control. Cows in these groups had two 300-d lactations during the 2-yr duration of the experiment (separated by a 56 -d dry period). Cows that failed to conceive in the first year or conceived late were replaced by similar cows for the second lactation, including 4 replacement primiparous cows. 


\section{Feeding and Management of Cows Grazing Pasture}

Cows were managed in the dry cow herd at DPI Ellinbank before the commencement of the experiment (calving). They were offered a maintenance allowance of pasture until approximately 2 wk before their expected calving date when they were brought to the calving pad and fed a barley-based dry cow ration with supplementary straw to achieve a BCS at calving of 5 on the 8-point scale of Earle (1976). Cows in the control 300 group were managed in a similar fashion as above when they were dry in between their two 10-mo lactations.

The 6 herds $(\mathrm{n}=12$ per herd) receiving the control 300 , control 670 , or high 670 treatments each grazed separately on a dedicated series of paddocks. Every cow was electronically identified and milked twice daily through a herringbone dairy at about 0700 and $1530 \mathrm{~h}$. They were individually fed a cereal grain supplement at each milking.

Nutrition for lactating cows was kept as similar as possible throughout the experiment by providing an estimated minimum daily dietary intake of either 160 (control 300 and control 670 groups) or $180 \mathrm{MJ}$ of ME/ cow (high 670 group). The high 670 group is described first as it was offered a similar level of nutrition to that described previously by Auldist et al. (2007). Briefly, it was calculated that this level of ME intake would enable cows to produce $280 \mathrm{~kg}$ of milk fat in a 10-mo lactation (Standing Committee on Agriculture, 1990). This energy was provided primarily by grazed pasture. When pasture availability or quality was limiting, the balance of the $180 \mathrm{MJ}$ of ME was met with cereal grain, pasture silage, and legume hay. Cows were allowed to consume more than $180 \mathrm{MJ}$ of ME per day from pasture when it was available.

Because of the inherent difficulty in measuring daily pasture intake, the collective energy intake was backcalculated at regular intervals using equations based on known energy requirements for the prevailing levels of milk production, BW, and BW change (Standing Committee on Agriculture, 1990). In accordance with the calculated ME intake, the diet was then adjusted as necessary to ensure that $180 \mathrm{MJ}$ of ME was being provided. This involved adjusting the pasture allowance (using electric fencing) and varying the supplementary grain and forage.

The groups on the control diets (control 300 and control 670) were provided with an estimated minimum daily dietary intake of $160 \mathrm{MJ}$ of ME/cow. This was achieved by offering these groups about $2.2 \mathrm{~kg}$ DM of grain/cow per day less than the cows in the high 670 group. It was calculated that this level of intake would enable cows to produce $230 \mathrm{~kg}$ of milk fat in a 10-mo lactation (Standing Committee on Agriculture, 1990).
Pasture allowance and other dietary supplements offered were similar for the control and high diets.

The pasture intake of cows was supplemented with 0.9 to $4.5 \mathrm{~kg}$ of DM/d of grain (control diet) and 2.7 to $7.2 \mathrm{~kg} \mathrm{DM} / \mathrm{d}$ of grain (high diet) to maintain prescribed minimum daily energy intakes (Table 1 ). The grain was mostly barley, but some triticale was also used. Totals of 0.73 and $1.40 \mathrm{t}$ of $\mathrm{DM}$ grain/cow were consumed in the first 10 mo for cows on the control and high diets, respectively. The high 670 cows consumed an extra 2.5 $\mathrm{kg}$ of DM grain/d between d 301 and 670 compared with the control 670 cows. The pasture intake of cows was supplemented with pasture silage as required from February to June 2005 and from February to May 2006 (Table 2). Alfalfa hay was used to supplement the diet in July 2005 because of a lack of pasture silage (Table 2) Nutrient composition of supplements is in Table 2.

\section{Feeding and Management of TMR Cows}

Cows allocated to the full TMR 670 treatment were managed in a separate dry cow herd at DPI Ellinbank before the commencement of the experiment (calving). Intakes were greater than in the other groups to enable them to reach a higher average BCS of 5.5 at calving. The higher BCS was to allow for the expected higher rate of BCS loss in early lactation for cows on the TMR diet compared with the pasture-based diets. Cows were offered a maintenance allowance of pasture and supplemented with alfalfa hay until approximately $3 \mathrm{wk}$ before their expected calving date when they were brought to the cattle barn and fed a TMR diet formulated for dry cows. The transition ration comprised (DM basis) 2.7 $\mathrm{kg}$ of wheat, $1.4 \mathrm{~kg}$ of canola meal, $3 \mathrm{~kg}$ of maize silage, $3 \mathrm{~kg}$ of alfalfa hay, $50 \mathrm{~g}$ of limestone, and $150 \mathrm{~g}$ of magnesium chloride.

The 2 replicate herds in the full TMR 670 treatment were separately fed ad libitum as a group in a cattle barn on a TMR from 0800 to $1230 \mathrm{~h}$ and from 1600 to $0430 \mathrm{~h}$. These cows were fed according to NRC (1989) requirements for high production. Because of high weight gain by up to half the cows that became obvious from about 350 DIM, an adjustment was made to the amount of TMR offered and at about 440 DIM the TMR was no longer offered ad libitum, but was reduced by about $2 \mathrm{~kg}$ of $\mathrm{DM} / \mathrm{d}$. The TMR was mixed twice daily using a Keenan Klassik mixer wagon (Richard Keenan and Co. Ltd., Borris, Co. Carlow, Ireland). When cows were not feeding, they were on a sawdust loafing area. They were milked twice daily through a parlor at about 0600 and $1500 \mathrm{~h}$ (before cows in the other groups). In addition to the TMR, cows received $1.8 \mathrm{~kg} \mathrm{DM} / \mathrm{d}$ of cracked grain (barley or triticale) at milking times. The extra grain was provided because the cows were used to 
Table 1. Nutrient composition of pasture offered by season to control 300, control 670, high 670 treatment groups and average nutrient composition of TMR diet (mean \pm SD) offered to full TMR treatment group and grain offered to control 300 and control 670 groups, and high 670 group

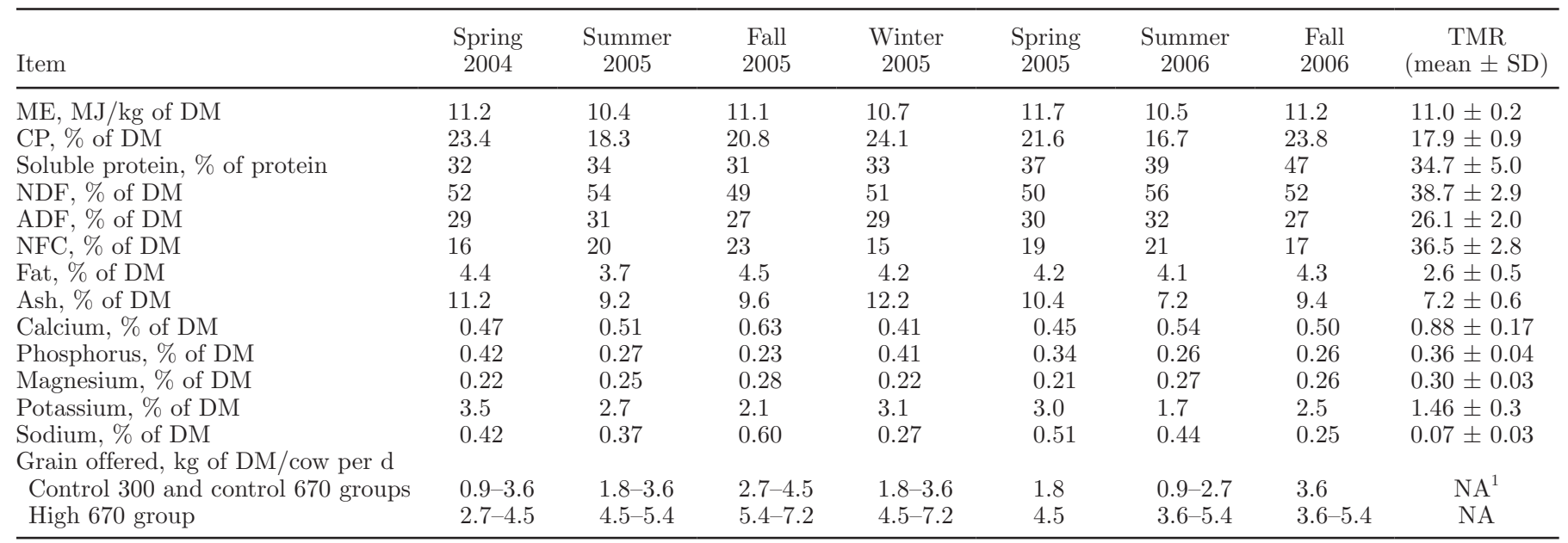

${ }^{1} \mathrm{NA}=$ not applicable.

receiving grain at the dairy and if no grain were offered it may have upset the cows during the milking process, reducing their milk yield and thereby confounding the results. The amount of grain offered was the minimum that could be accurately dispensed.

The TMR was formulated by Keenan Pty. Ltd. (Bendigo, Australia) using a commercial rationing service $\left(\right.$ FeedByte $\left.^{2.38}\right)$. The ration was changed as required based on changes in the cows' requirements and changes in the ingredients used. At about 450 DIM the amount of TMR offered per cow was reduced by about $2 \mathrm{~kg}$ of $\mathrm{DM} / \mathrm{d}$ to prevent excessive $\mathrm{BW}$ gain. Pasture and maize silage was used over the 2 yr. The approximate proportions (DM basis) of the components in the TMR were wheat/barley/triticale (17\%), canola meal (14\%), alfalfa hay (34\%), maize silage (16\%), grass silage $(13 \%)$, minerals $(1 \%)$, and cereal straw $(5 \%)$.

The mineral mix was a standard Keenan powder mix (Keenan Pty. Ltd.) and was added to the TMR at the rate of $250 \mathrm{~g} / \mathrm{cow}$. The composition of the mix was limestone (125 g), magnesium oxide (37.5 g), dicalcium phosphate $(62.5 \mathrm{~g})$, sodium monensin $(250 \mathrm{mg})$, zinc (1050 mg), manganese (920 mg), copper (350 mg), iodine (10 mg), cobalt (20 mg), selenium (6 mg), vitamin A (70,000 IU), vitamin D3 (12,000 IU), and vitamin E (600 IU).

\section{Breeding Program}

All cows in the experiment were enrolled in a breeding program that involved the synchronization of estrus using a controlled internal drug-releasing (CIDR) insert that allowed progesterone to be administered per vaginum combined with intramuscular injections of estradiol benzoate for ovarian follicle management and prostaglandin $\mathrm{F}_{2 \alpha}$ for luteolysis as has been described previously by Auldist et al. (2007). This protocol was implemented over a period of $8 \mathrm{~d}$ to every cow in each herd, with individual animals being inseminated following detected estrus. The first day of insemination was highly synchronized and was designed to occur so that cows that conceived on that date would calve about

Table 2. Nutrient composition of supplements offered to control 300, control 670, and high 670 treatment groups $^{1}$

\begin{tabular}{|c|c|c|c|c|c|}
\hline Supplement & Period of feeding & $\begin{array}{c}\text { Amount offered, } \\
\text { kg of DM/ } \\
\text { cow per d }\end{array}$ & $\begin{array}{c}\text { Energy, MJ } \\
\text { of } \mathrm{ME} / \mathrm{kg} \text { of } \mathrm{DM}\end{array}$ & $\mathrm{CP}, \%$ & NDF, $\%$ \\
\hline Grain & July 2004 to June 2006 & Refer to Table 1 & $13.1(0.4)$ & $13.6(1.4)$ & $7.0^{2}(1.8)$ \\
\hline Pasture silage & February to June 2005 & $7.8-10.2$ & $10.6(0.6)$ & $17.0(1.0)$ & $53.7(4.0)$ \\
\hline Alfalfa hay & July 2005 & $5.9-6.7$ & $8.0(0.2)$ & $17.6(0.6)$ & $47.3(0.2)$ \\
\hline Pasture silage & February to March 2006 & $6.7-10.2$ & $10.7(0.6)$ & $14.5(0.5)$ & $57.1(4.3)$ \\
\hline
\end{tabular}


282 d later on a date coinciding with the concentrated calving pattern initiating the following lactations with average calving intervals of 12 or 24 mo. There were 3 rounds of AI over a period of 6 wk followed by sire service to an observed heat for a total breeding period of 12 wk. Cows were pregnancy tested 6 to 8 wk after the end of the breeding program. Insemination data and intervals to conception were not included in statistical analyses because group sizes for fertility results were small and confounded by levels of nutrition.

\section{Dry-Off Threshold}

Cows that had an average milk yield $<30 \mathrm{~kg} /$ wk for 2 consecutive weeks were dried off irrespective of whether they had met their lactation target. Those cows that maintained production above $30 \mathrm{~kg} /$ wk for the entire lactation were dried off $56 \mathrm{~d}$ before their expected calving date.

\section{Measurements and Analyses}

Milk yield was measured daily for each cow using a DeLaval ALPRO milk metering system (DeLaval International, Tumba, Sweden). Separate a.m. and p.m. milk samples were taken on $1 \mathrm{~d}$ every 2 wk from each cow using in-line milk meters. Samples were analyzed for concentrations of fat, protein, and lactose using a near-infrared milk analyzer (model 2000, Bentley Instruments, Chaska, MN). The ratio of milk solids (annualized/normal) was calculated for cows in the control 670, high 670, and full TMR 670 groups, where "annualized" was the milk solids production achieved during the 24-mo calving interval divided by $2 \mathrm{yr}$, and "normal" was the milk solids production produced in a 12-mo calving interval (Kolver et al., 2008). This ratio gives an indication of the proportion of annualized milk solids produced in the extended-lactation system over a 2 -yr period compared with milk solids produced in the normal 12-mo calving system. Cows were weighed and condition scored monthly during the experiment.

Measurements of average intake (DM/cow) with the 2 full TMR 670 replicate groups were made every 6 to 8 wk by weighing feed offered and refused by each group on 4 consecutive days. Samples of pasture and other feeds including TMR offered to cows were collected once every 6 to $8 \mathrm{wk}$ and averaged by season. These feed samples were frozen, freeze-dried, ground through a $0.5-\mathrm{mm}$ sieve, and analyzed for nutritive characteristics by near-infrared spectroscopy by a commercial laboratory (Dairy One Forage Laboratory, Ithaca, NY).

\section{Statistical Analyses}

Milk weight, fat yield, protein yield, and lactose yield totals were derived for each animal for 1 to $300 \mathrm{~d}$ in all treatments, and for 301 to $670 \mathrm{~d}$ in extended lactation treatments. Fat, protein, lactose, and total solids percentage values for each replicate group were given by the corresponding yield totals divided by milk weights. The data were unbalanced insofar as there were 2 herds of 12 animals for each treatment, with the control 300 treatment herds alone having 12 replacement animals in the second year including 4 primiparous cows.

Each variable was analyzed using a general linear mixed model in which the fixed effects were specified as treatment (4 levels: control 300, control 670, high 670 , and full TMR 670) by year (2 levels: 0 to $300 \mathrm{~d}$ and 301 to $670 \mathrm{~d}$ ). The random effects were specified as herd split for animal, plus herd $\times$ year, plus a residual error (herd $\times$ year $\times$ animal). Fixed effects also included a covariate term for the percentage Northern Hemisphere genes allowing for the possibility of different effects with treatments and year. The significance of main effects of treatment and treatment by year were tested using Wald tests. Pairwise differences between treatment means were tested using SED and approximate 1-tailed $t$-tests on $4 \mathrm{df}$ for main effects, or $8 \mathrm{df}$ for effects of treatment within year. One-sided $t$-tests were used because treatments with higher inputs were expected to produce higher means.

To better approximate treatment fat, protein, and lactose percentage means, weights were included in the analysis at the lowest stratum. The weights were defined for each datum as the milk yield divided by its herd total milk yield. The main effect means for treatments were also calculated as a weighted average of the estimated treatment by year means, where the weights were given by the proportions of milk yield for each year within each treatment. The SED were calculated using standard normal matrix theory for variances of these linear combinations.

Change in daily milk yield and milk solids yield between 324 and 428 DIM, and the milk solids ratio (annualized/normal) were analyzed for the 3 extendedlactation treatments using ANOVA with blocking structure as herd split for animal.

Body weight and BCS changes were derived for each animal for 1 to $300 \mathrm{~d}$ in all treatments, and for 1 to 670 $\mathrm{d}$ in extended-lactation treatments. The BCS changes were calculated from immediately before calving and BW changes from approximately $7 \mathrm{~d}$ after calving. The balanced 1 to $300 \mathrm{~d}$ data were subjected to simple ANOVA to compare the 4 levels of treatment, using blocking structure as herd split for animal. The 1 to 670 d change data for the 3 extended-lactation treatments and the control $300 \mathrm{~d}$ treatment ( 1 to $300 \mathrm{~d}$ and 301 to $670 \mathrm{~d}$ ) change data were analyzed using a general linear mixed model with treatment as the fixed effect and random effects for herd and animal. 


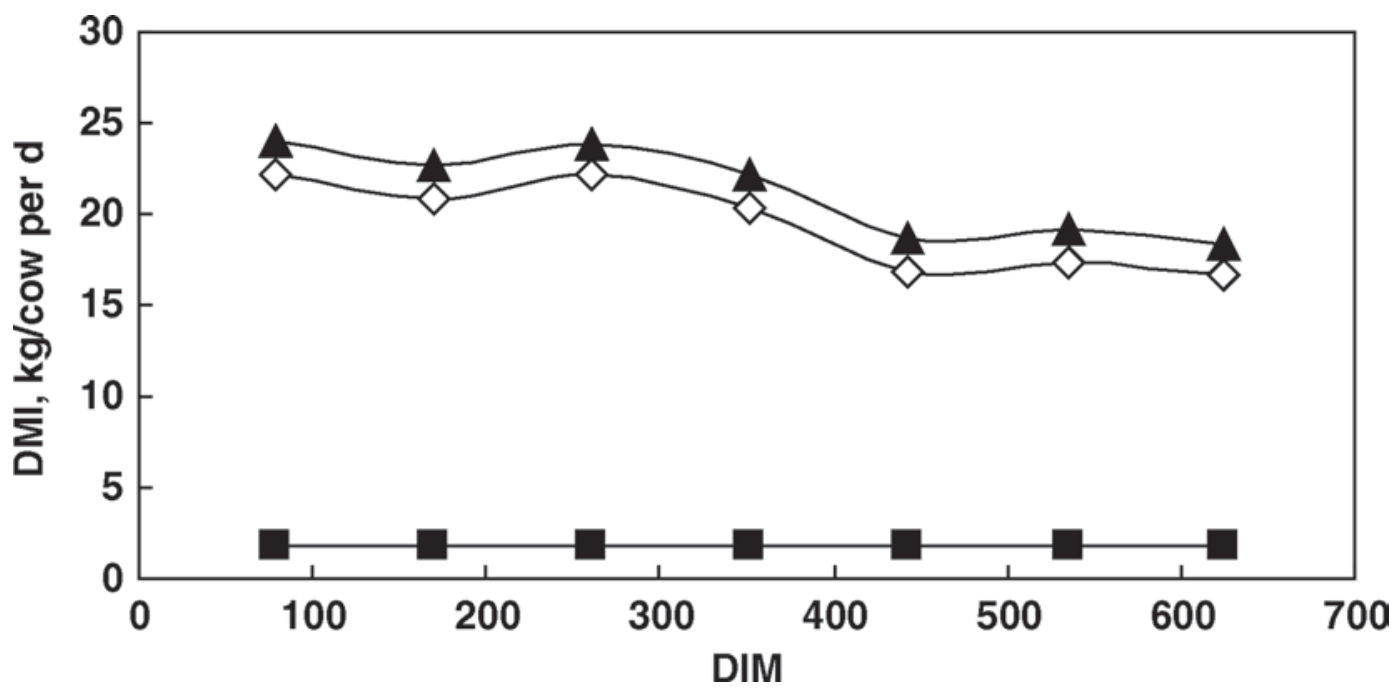

Figure 1. Dry matter intakes of cows in the full TMR 670 treatment group comprising intakes of cracked cereal grain $(\mathbf{\square})$, TMR $(\diamond)$, and total intake $(\boldsymbol{\Lambda})$. Each data point is the average intake of the 2 replicate groups for all lactating cows in the full TMR 670 group.

Residuals were examined for normality of distribution and constant variance using graphs of residuals versus fitted values, histograms, quantile plots, and residuals by herd and year. Where required (all yield variables and lactose percentage), an additional variance component was included in the model to allow for increased variance between animals in yr 2 for the full TMR 670 treatment. Analyses were performed using REML (GenStat, 2007a).

The time to dry-off was compared between the 3 extended-lactation treatments using the Wilcoxon (Peto-Prentice) nonparametric survival analysis test (Collett, 1994). Analysis was performed using the KAPLANMEIER and RSTEST procedures (GenStat, 2007b).

\section{RESULTS}

\section{Animal Health and Fertility}

The cows in the full TMR 670 group were offered their TMR in the cattle barn. At the start of the lactation the cows were standing on concrete when they were feeding, but 8 of the cows developed lameness, resulting in an average decline in milk yield of these cows of 3.8 $\mathrm{kg} / \mathrm{d}$ from 50 to 90 DIM. This resulted in a more rapid decline from peak yield than expected for the full TMR 670 group. The problem with lameness was corrected by providing rubber matting and by increasing the animals' time on an adjacent sawdust loafing area.

Twelve of the cows in the control 300 replicate groups in yr 1 that either failed to conceive or conceived late were replaced in yr 2 by similar cows including 4 primiparous replacement cows.

\section{Diet}

The nutrient composition of the pasture was generally high except for the summer period when the ME and CP concentrations declined (Table 1). The TMR contained an ME concentration similar to the pasture, but less CP, NDF, and fat and more NFC than pasture during the 2-yr study. Average DMI of the full TMR 670 group was initially high $(24.0 \mathrm{~kg} / \mathrm{cow})$, declined, and then recovered, decreasing at about 440 DIM to approximately $18.5 \mathrm{~kg} / \mathrm{cow}$ when the amount of TMR offered was reduced by about $2 \mathrm{~kg}$ of DM/d (Figure $1)$.

\section{Proportion of Cows Reaching Their Target Lactation Length}

The proportion of cows still milking after a 670-d lactation was similar for the control and high dietary groups (Figure 2). The full TMR group had numerically fewer cows milking after 500 DIM. This was only significant at 600 DIM when 17 cows were milking in the full TMR group compared with 24 cows in the control 670 group $(P=0.005)$ and 22 cows in the high 670 group $(P=0.068)$. The percentage of cows still milking at 650 DIM was $58 \%$ (control 670 group), 50\% (high 670 group), and $42 \%$ (full TMR 670 group).

\section{$B W$ and BCS at Calving}

The precalving BCS and BW (mean \pm SD) for the treatment groups were $4.9 \pm 0.3$ and $582 \pm 71 \mathrm{~kg}$ (control $300 \mathrm{yr} 1), 4.7 \pm 0.3$ and $592 \pm 59 \mathrm{~kg}$ (control 300 yr 2), $4.9 \pm 0.4$ and $582 \pm 72 \mathrm{~kg}$ (control 670), $4.7 \pm$ 


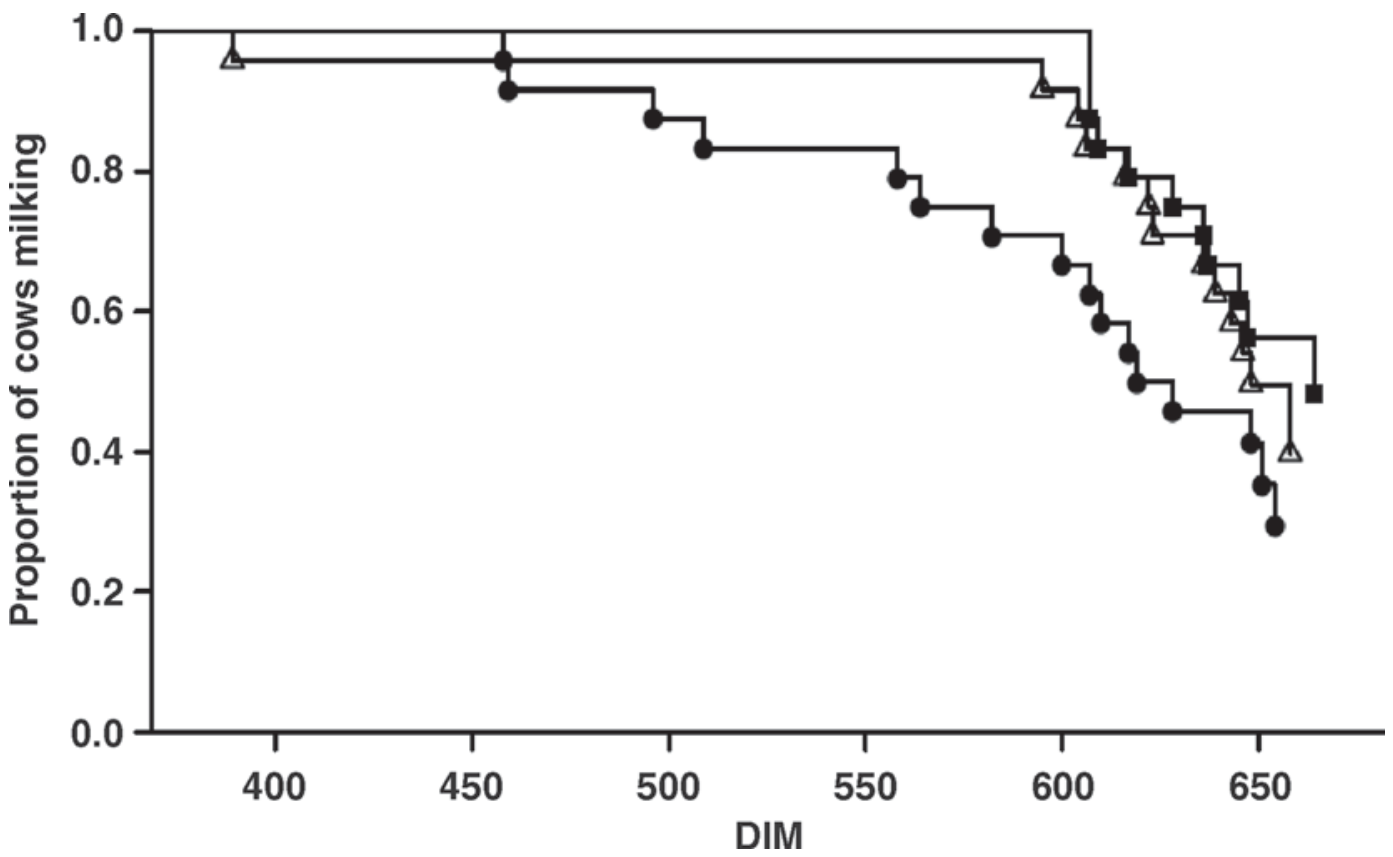

Figure 2. Kaplan-Meier survival curves for the proportion of cows still milking during a 670-d lactation for cows undergoing lactations of 670-d offered a control $(\square)$, high $(\Delta)$, or full TMR $(\bullet)$ diet; DIM was measured from calving date for each animal and data were censored at $14 \mathrm{~d}$ before final dry-off date.

0.2 and $569 \pm 72 \mathrm{~kg}$ (control 670), and $5.2 \pm 0.3$ and $605 \pm 95 \mathrm{~kg}$ (full TMR 670).

\section{Yields of Milk and Milk Solids}

Milk and milk solids (protein + fat) production for the different treatment groups are presented in Figure 3. The covariate term for the percentage Northern Hemisphere genes was not significant $(P>0.05)$ for any of the variables and consequently has not been presented.

There was an increase in yield of milk and some milk components from 1 to 300 DIM with improved energy level in the diet (control vs. high) and full TMR system (includes higher BCS at calving) except for milk fat yield of cows receiving the high diet compared with the control diet (Table 3). Milk fat, protein, and lactose concentrations were generally increased with improved energy level in the diet except for fat and lactose concentration of the high diet compared with the control diet (Table 3). From 301 to 670 DIM there was no effect of type of diet or increased energy level on yields of milk and milk components. The only significant effect on milk composition was an increase in milk protein percentage of the high 670 and full TMR 670 groups compared with the control 670 group (Table 4). The ratio of milk solids (annualized/normal) for the 3 extended-lactation groups was not affected by increasing the level of grain in the pasture-based diets (0.93 vs. 0.90 for control and high diets), but decreased with the TMR diet (0.79).

The yields of milk and milk components from 1 to 670 DIM were similar for the control 300 group compared with the control 670 group, but the milk fat and protein concentrations of the milk were increased in the latter group (Table 5). Increasing the energy level in the diet (control 670 vs. high 670) resulted in a similar yield of milk and milk lactose and a similar fat concentration in the milk, but greater yields of milk fat and protein and a greater milk protein percentage of the milk. The full TMR 670 group produced greater yields of milk and milk components (fat, protein, and lactose) and also protein percentage in the milk than the other groups. There was a small increase in lactose percentage of the milk for the high 670 and full TMR groups (Table 5).

There was an increase in milk and milk solids yields from the winter period to the second spring period for the control 670 and high 670 treatment groups, but the full TMR 670 group declined in milk and milk solids yields over the same period (Table 6 and Figure 3 ).

\section{Changes in BCS and BW}

The full TMR 670 group had greater gains in mean BCS and BW than the other 3 treatment groups for the first 300 DIM and from 301 to 670 DIM (Tables 3 

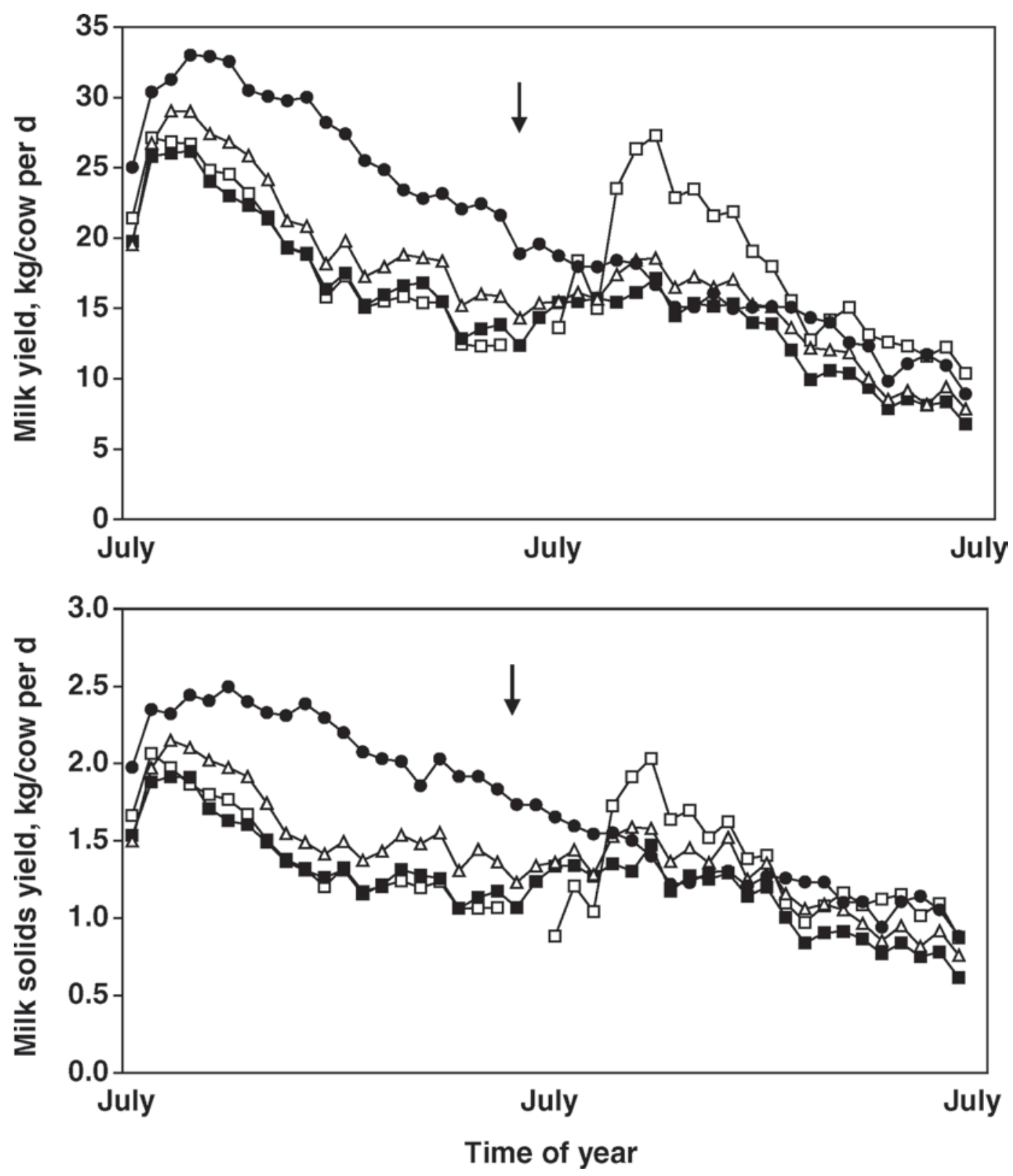

Figure 3. Lactation curves for the production of milk and milk solids (protein + fat) for cows undergoing 2 lactations of 300-d offered a control diet $(\square)$ or lactations of 670 -d offered a control $(\mathbf{\square})$, high $(\Delta)$, or full TMR $(\bullet)$ diet. Data are means for all lactating cows; arrows indicate time of dry off for the control herd in their first lactation.

and 4). The BW and BCS gains were greatest for the full TMR 670 group followed by the high 670 group, the control 670 group, and the control 300 groups over the whole period from 1 to 670 DIM (Table 5).

\section{DISCUSSION}

The present study has provided new evidence about the ability of cows to milk for a 670-d lactation when offered lower energy levels than previously reported on pasture-based diets supplemented with cereal grain or concentrate (Auldist et al., 2007; Kolver et al., 2008), and also when offered a full TMR diet system. Increasing the level of nutrition on pasture-based and TMR diets improved the total milk production of cows in an extended lactation. However, increasing the level of nutrition for cows offered pasture-based diets did not improve the performance of cows in extended lactation as measured by the milk solids ratio (annualized/normal) and the percentage of cows milking at drying-off, 
Table 3. Lactation yields of milk, fat, protein, and milk solids (protein + fat), and concentrations of fat, protein and lactose, and changes in BW and BCS for 1 to $300 \mathrm{~d}$ of lactation for cows offered a control, high, or full TMR diet and designated to lactate for 300 or $670 \mathrm{~d}$

\begin{tabular}{lccccc}
\hline Item & Control 300 & Control 670 & High 670 & Full TMR 670 & SED \\
\hline Milk yield, kg/cow & $5,807^{\mathrm{a}}$ & $5,963^{\mathrm{a}}$ & $6,672^{\mathrm{b}}$ & $8,613^{\mathrm{c}}$ & 329.4 \\
Fat yield, kg/cow & $249.5^{\mathrm{a}}$ & $253.0^{\mathrm{a}}$ & $293.3^{\mathrm{ab}}$ & $384.1^{\mathrm{c}}$ & 12.32 \\
Protein yield, kg/cow & $188.6^{\mathrm{a}}$ & $191.3^{\mathrm{a}}$ & $221.1^{\mathrm{b}}$ & $303.6^{\mathrm{c}}$ & 10.80 \\
Lactose yield, kg/cow & $286.6^{\mathrm{a}}$ & $295.7^{\mathrm{a}}$ & $334.7^{\mathrm{b}}$ & $435.7^{\mathrm{c}}$ & 17.52 \\
Milk solids yield, kg/cow & $438.5^{\mathrm{a}}$ & $444.2^{\mathrm{a}}$ & $514.3^{\mathrm{b}}$ & $687.7^{\mathrm{c}}$ & 22.28 \\
Fat, $\%$ & $4.28^{\mathrm{ab}}$ & $4.24^{\mathrm{a}}$ & $4.42^{\mathrm{ab}}$ & $4.48^{\mathrm{b}}$ & 0.112 \\
Protein, $\%$ & $3.23^{\mathrm{a}}$ & $3.21^{\mathrm{a}}$ & $3.32^{\mathrm{b}}$ & $3.54^{\mathrm{c}}$ & 0.048 \\
Lactose, \% & $4.96^{\mathrm{a}}$ & $4.96^{\mathrm{a}}$ & $5.02^{\mathrm{ab}}$ & $5.07^{\mathrm{b}}$ & 0.040 \\
BW change, ${ }^{1} \mathrm{~kg} / \mathrm{cow}$ & $65^{\mathrm{a}}$ & $43^{\mathrm{a}}$ & $57^{\mathrm{a}}$ & $104^{\mathrm{b}}$ & 13.3 \\
BCS change, ${ }^{\mathrm{a}}$ units/cow & $-0.40^{\mathrm{a}}$ & $-0.40^{\mathrm{a}}$ & $-0.28^{\mathrm{a}}$ & $0.36^{\mathrm{b}}$ & 0.123 \\
\hline
\end{tabular}

${ }^{\mathrm{a}-\mathrm{c}}$ Group means with different superscripts are significantly different $(P<0.05,1$-tailed test $)$.

${ }^{1} \mathrm{BW}$ change calculated from 1 wk postcalving.

${ }^{2} \mathrm{BCS}$ change calculated from immediately before calving.

and this agrees with observations made by Kolver et al. (2008). In contrast, the cows offered the higher quality TMR diet had a lower milk solids ratio $(0.79$ vs. $>0.90)$ and a lower percentage of cows milking at 600 DIM than cows on pasture-based diets (71 vs. $>92 \%$ ). The control 670 group was on a low level of nutrition and produced $7.1 \%$ less milk but only $2.4 \%$ less milk solids compared with the control 300 group over the 2-yr period of the study. Comparable data from Auldist et al. (2007) but at a higher level of nutrition were $10.5 \%$ less milk and $6.9 \%$ less milk solids. This data would support the assertion by Kolver et al. (2008) that the extendedlactation concept is best suited to lower production, pasture-based systems. The responses differed for the 2 diet types and need to be considered separately.

\section{Pasture-Based Diets}

Data from the present study were combined with 2 previously reported studies on extended lactation in Table 7 (Auldist et al., 2007; Kolver et al., 2008). The study of Auldist et al. (2007) produced data for a 22-mo lactation in which the level of nutrition was similar to the high 670 group in the present study as indicated by the 300-d milk solids yield (mean \pm SEM) of $505 \pm 14.1$ versus $514 \pm 13.7 \mathrm{~kg} /$ cow. In the study of Kolver et al. (2008) cows of 2 differing strains, New Zealand (NZ) or North American (NA) Holstein-Friesian, were offered pasture and 3 levels of concentrate $(0,3$, and $6 \mathrm{~kg}$ of $\mathrm{DM} /$ cow per d) over a 22-mo lactation. For the purpose of this discussion, the NA Holstein-Friesians used

Table 4. Lactation yields of milk, fat, protein, and milk solids (protein + fat), ratio of annualized extended lactation versus normal lactations, concentrations of fat, protein, and lactose, and changes in BW and BCS for 301 to $670 \mathrm{~d}$ of lactation for cows offered a control, high, or full TMR diet and designated to lactate for $670 \mathrm{~d}$

\begin{tabular}{lccccc}
\hline Item & Control 670 & High 670 & Full TMR 670 & SED1 ${ }^{1}$ & SED2 \\
\hline Milk yield, kg/cow & $4,316^{\mathrm{a}}$ & $4,591^{\mathrm{a}}$ & $4,618^{\mathrm{a}}$ & 329.4 & 513.8 \\
Fat yield, kg/cow & $209.8^{\mathrm{a}}$ & $227.6^{\mathrm{a}}$ & $219.6^{\mathrm{a}}$ & 12.32 & 22.36 \\
Protein yield, kg/cow & $162.9^{\mathrm{a}}$ & $179.0^{\mathrm{a}}$ & $181.0^{\mathrm{a}}$ & 10.8 & 19.9 \\
Lactose yield, kg/cow & $212.9^{\mathrm{a}}$ & $230.0^{\mathrm{a}}$ & $231.1^{\mathrm{a}}$ & 17.52 & 27.09 \\
Milk solids yield, kg/cow & $372.8^{\mathrm{a}}$ & $406.6^{\mathrm{a}}$ & $400.6^{\mathrm{a}}$ & 22.28 & 42.01 \\
Milk solids ratio & $0.93^{\mathrm{a}}$ & $0.90^{\mathrm{a}}$ & $0.79^{\mathrm{b}}$ & 0.034 & 0.034 \\
Fat, \% & $4.89^{\mathrm{a}}$ & $4.99^{\mathrm{a}}$ & $4.81^{\mathrm{a}}$ & 0.112 & 0.112 \\
Protein, \% & $3.78^{\mathrm{a}}$ & $3.91^{\mathrm{b}}$ & $3.91^{\mathrm{b}}$ & 0.048 & 0.048 \\
Lactose, \% & $4.92^{\mathrm{a}}$ & $5.00^{\mathrm{a}}$ & $4.92^{\mathrm{a}}$ & 0.040 & 0.052 \\
BW change, kg/cow & $99^{\mathrm{a}}$ & $116^{\mathrm{a}}$ & $141^{\mathrm{b}}$ & 11.4 & 11.4 \\
BCS change, units/cow & $0.63^{\mathrm{a}}$ & $0.85^{\mathrm{a}}$ & $3.29^{\mathrm{b}}$ & 0.166 & 0.166 \\
\hline
\end{tabular}

${ }^{\mathrm{a}, \mathrm{b}}$ Group means with different superscripts are significantly different $(P<0.05,1$-tailed test $)$.

${ }^{1} \mathrm{SED} 1$ is the standard error for comparing treatment means except when comparing with the full TMR 670 group mean when SED2 should be used.

${ }^{2}$ Milk solids ratio (annualized/normal) where annualized is the milk solids production achieved during the 24-mo calving interval divided by 2 yr and normal is the milk solids production produced in a normal 12-mo calving interval (Kolver et al., 2008). 
Table 5. Lactation yields of milk, fat, protein, and milk solids (protein + fat), concentrations of fat, protein, and lactose, and changes in BW and BCS for 1 to $670 \mathrm{~d}$ of lactation for cows offered a control, high, or full TMR diet and designated to lactate for 300 or $670 \mathrm{~d}$

\begin{tabular}{|c|c|c|c|c|c|c|}
\hline Item & $\begin{array}{l}\text { Control } 300 \\
\text { Year } 1+2^{1}\end{array}$ & Control 670 & High 670 & Full TMR 670 & $\mathrm{SED}^{2}{ }^{2}$ & SED2 \\
\hline Milk yield, $\mathrm{kg} / \mathrm{cow}$ & $11,060^{\mathrm{a}}$ & $10,279^{\mathrm{a}}$ & $11,263^{\mathrm{a}}$ & $13,231^{\mathrm{b}}$ & 623.9 & 738.1 \\
\hline Fat yield, $\mathrm{kg} / \mathrm{cow}$ & $475.3^{\mathrm{a}}$ & $462.8^{\mathrm{a}}$ & $520.8^{\mathrm{b}}$ & $603.6^{\mathrm{c}}$ & 23.14 & 29.73 \\
\hline Protein yield, $\mathrm{kg} / \mathrm{cow}$ & $361.2^{\mathrm{a}}$ & $354.2^{\mathrm{a}}$ & $400.1^{\mathrm{b}}$ & $484.6^{\mathrm{c}}$ & 20.09 & 26.16 \\
\hline Lactose yield, $\mathrm{kg} / \mathrm{cow}$ & $548.8^{\mathrm{a}}$ & $508.6^{\mathrm{a}}$ & $564.7^{\mathrm{a}}$ & $666.8^{\mathrm{b}}$ & 33.27 & 39.16 \\
\hline Milk solids yield, $\mathrm{kg} / \mathrm{cow}$ & $836.7^{\mathrm{a}}$ & $817.0^{\mathrm{a}}$ & $920.9^{\mathrm{b}}$ & $1,088.3^{\mathrm{c}}$ & 41.61 & 54.77 \\
\hline Fat, $\%$ & $4.29^{\mathrm{a}}$ & $4.51^{\mathrm{b}}$ & $4.65^{\mathrm{b}}$ & $4.60^{\mathrm{b}}$ & 0.091 & 0.091 \\
\hline Protein, \% & $3.26^{\mathrm{a}}$ & $3.45^{\mathrm{b}}$ & $3.56^{\mathrm{c}}$ & $3.67^{\mathrm{d}}$ & 0.041 & 0.041 \\
\hline Lactose, $\%$ & $4.97^{\mathrm{ab}}$ & $4.94^{\mathrm{a}}$ & $5.01^{\mathrm{ab}}$ & $5.04^{\mathrm{b}}$ & 0.036 & 0.036 \\
\hline BW change, ${ }^{3} \mathrm{~kg} /$ cow & $69^{\mathrm{a}}$ & $143^{\mathrm{b}}$ & $173^{\mathrm{c}}$ & $245^{\mathrm{d}}$ & 11.4 & 11.4 \\
\hline BCS change, ${ }^{4}$ units/cow & $-0.20^{\mathrm{a}}$ & $0.22^{\mathrm{b}}$ & $0.59^{\mathrm{c}}$ & $3.64^{\mathrm{d}}$ & 0.079 & 0.079 \\
\hline
\end{tabular}

${ }^{\mathrm{a}-\mathrm{d}}$ Group means with different superscripts are significantly different $(P<0.05,1$-tailed test).

${ }^{1}$ Control 300 Year 1 and 2 is the sum of data for yr 1 and 2 for this treatment group except for BW and BCS change, which are the average of yr 1 and 2 .

${ }^{2} \mathrm{SED} 1$ is the standard error for comparing treatment means except when comparing with the full TMR 670 group mean when SED2 should be used.

${ }^{3} \mathrm{BW}$ change calculated from 1 wk postcalving.

${ }^{4} \mathrm{BCS}$ change calculated from immediately before calving.

by Kolver et al. (2008) have been defined as Northern Hemisphere Holsteins.

To enable comparisons between studies, the milk solids yield produced by 300 DIM, rather than the amount of grain offered/cow, is the best indicator of the level of nutrition (Table 7). The lowest level of nutrition was in the control 670 treatment group (present study) and the highest was the NA6 treatment group (Kolver et al., 2008). The percentage of cows from Northern Hemisphere strains varied from $<12.5$ to $>88 \%$.

Two main effects to be considered are cow genotype and level of nutrition. Kolver et al. (2008) concluded that cows with a high proportion of Northern Hemisphere genes $(>88 \%)$ had a higher milk solids ratio of 0.94 compared with 0.79 for cows with a lower level $(<12.5 \%)$ of Northern Hemisphere genes. In addition, the percentage of cows milking just before the planned drying-off date was higher (48 vs. 14\%), and the BW gain over the lactation was lower (128 vs.170 kg). The additional data provided by Auldist et al. (2007) and the present study are for cows with about $63 \%$ Northern Hemisphere genes and provide supporting data for the conclusions made by Kolver et al. (2008). The evidence is less clear-cut for the data related to BW change. Even though the cows in the present study had a lower proportion of Northern Hemisphere genes and were progeny of sires that had been selected for fat plus protein yield, the results demonstrated that they were of similar suitability to the Northern Hemisphere cows used by Kolver et al. (2008) for extended lactations with nutritional management based on pasture supplemented with grain (Table 7).

In contrast, there was no clear effect of level of nutrition on the milk solids ratio or the percentage of cows milking at drying-off. There was, however, an increase in BW gain over lactation with increasing level of nutrition. These findings mean that for optimum extended-lactation performance, it is preferable to use cows with a high proportion of Northern Hemisphere genes. Improving the overall level of nutrition did not result in improved extended-lactation performance as measured by the milk solids ratio and the percentage of cows milking at drying-off.

The concentrations of fat and protein in the milk were consistently greater $(0.53$ and $0.56 \%)$ in the extended lactation phase compared with normal lactation length

Table 6. Changes in milk and milk solids (protein + fat) yield from 324 to 428 DIM (winter to second spring) for cows offered a control, high, or full TMR diet and designated to lactate for $670 \mathrm{~d}$

\begin{tabular}{lcccccc}
\hline & \multicolumn{3}{c}{ Treatment } & & \\
\cline { 2 - 4 } Item & Control 670 & High 670 & Full TMR 670 & & SED & $P$-value \\
\hline Milk, $\mathrm{kg} / \mathrm{d}$ & $4.4^{\mathrm{a}}$ & $3.5^{\mathrm{a}}$ & $-3.7^{\mathrm{b}}$ & 0.92 & $<0.001$ \\
Milk solids, $\mathrm{kg} / \mathrm{d}$ & $0.38^{\mathrm{a}}$ & $0.28^{\mathrm{a}}$ & $-0.41^{\mathrm{b}}$ & & 0.084 & $<0.001$ \\
\hline
\end{tabular}

${ }^{\mathrm{a}, \mathrm{b}}$ Group means with different superscripts are significantly different $(P<0.05)$. 
Table 7. Comparison of data from recent experiments that have studied extended lactation of dairy cows (Auldist et al., 2007; Kolver et al., 2008; present study)

\begin{tabular}{|c|c|c|c|c|c|c|c|c|c|c|}
\hline Study & Breed & $\begin{array}{c}\% \\
\text { N-Hemisphere } \\
\text { genes }\end{array}$ & $\begin{array}{l}\text { Grain, kg } \\
\text { of DM/cow }\end{array}$ & $\begin{array}{l}\text { Milk solids, } \\
\mathrm{kg} / \text { cow }^{1}\end{array}$ & $\begin{array}{l}\text { Milk solids } \\
\text { ratio }^{2}\end{array}$ & $\begin{array}{l}\text { Average } \\
\text { DIM }\end{array}$ & $\begin{array}{l}\text { Milking at } \\
\text { dry-off, \% }\end{array}$ & $\begin{array}{c}\text { BW gain } \\
\text { in lactation, } \\
\mathrm{kg} / \mathrm{cow}\end{array}$ & $\begin{array}{l}\text { Change } \\
\text { in fat } \%^{3}\end{array}$ & $\begin{array}{l}\text { Change in } \\
\text { protein } \%^{3}\end{array}$ \\
\hline \multicolumn{11}{|l|}{ Auldist et al. $(2007)^{4}$} \\
\hline 22-mo lactation & $\begin{array}{l}\text { Australian } \\
\text { Holstein }\end{array}$ & 62 & 5.3 & 505 & 0.93 & 643 & 42 & 188 & 0.52 & 0.50 \\
\hline \multicolumn{11}{|c|}{ Kolver et al. $(2008)^{5}$} \\
\hline NA0 & $\begin{array}{l}\text { American } \\
\text { Holstein }\end{array}$ & $>88$ & 0 & 494 & 0.89 & 623 & 38 & 92 & 0.36 & 0.64 \\
\hline NA3 & $\begin{array}{l}\text { American } \\
\text { Holstein }\end{array}$ & $>88$ & 3 & 556 & 1.00 & 604 & 56 & 118 & 0.51 & 0.65 \\
\hline NA6 & $\begin{array}{l}\text { American } \\
\text { Holstein }\end{array}$ & $>88$ & 5.6 & 625 & 0.94 & 630 & 50 & 175 & 0.65 & 0.52 \\
\hline NZ0 & NZ Friesian & $<12$ & 0 & 489 & 0.78 & 595 & 20 & 126 & 0.47 & 0.63 \\
\hline NZ3 & NZ Friesian & $<12$ & 3 & 551 & 0.83 & 608 & 22 & 203 & 0.45 & 0.55 \\
\hline \multirow{2}{*}{\multicolumn{11}{|c|}{ Present study ${ }^{6}$}} \\
\hline & & & & & & & & & & \\
\hline Control 670 & $\begin{array}{l}\text { Australian } \\
\text { Holstein }\end{array}$ & 64 & 2.7 & 444 & 0.93 & 652 & 58 & 143 & 0.65 & 0.57 \\
\hline High 670 & $\begin{array}{l}\text { Australian } \\
\text { Holstein }\end{array}$ & 64 & 5.1 & 514 & 0.90 & 636 & 50 & 173 & 0.57 & 0.59 \\
\hline Full TMR 670 & $\begin{array}{l}\text { Australian } \\
\text { Holstein }\end{array}$ & 64 & $\begin{array}{l}\text { TMR }+1.8 \\
\mathrm{~kg} \text { grain }\end{array}$ & 688 & 0.79 & 608 & 42 & 245 & 0.33 & 0.37 \\
\hline
\end{tabular}

${ }^{1}$ Fat + protein produced from d 1 to 300

${ }^{2}$ Ratio of milk solids (protein + fat; annualized extended lactation to normal 300-d lactation).

${ }^{3}$ Change in fat and protein percentage (extended lactation average d 301 to dry-off, average d 1 to 300 of lactation); milk composition data of Kolver et al. (2008) is from Turner et al. (2008).

$\quad{ }^{4}$ Treatment group from Auldist et al. (2007) was the 22-mo treatment.

on Treatments used in Kolver et al. (2008) were genotypes (North American, NA; or New Zealand, NZ) and grain feeding levels (0, 3, or 6 kg of DM/cow).

离. $\quad{ }^{6}$ In the present study cows were offered a control, high, or full TMR diet and designated to lactate for $670 \mathrm{~d}$. 
(Table 7). These increases in concentrations were not affected significantly by the level of nutrition or by the percentage of Northern Hemisphere genes in the cows. The increases in fat and protein concentration in the milk partly compensated for the decline in milk volume. This was illustrated by the control 670 group that produced $7.1 \%$ less milk but only $2.4 \%$ less milk solids than the 2 control 300 groups over the 2 -yr period of the study. The milk payment system used by most Australian dairy companies is based on payment for milk fat and milk protein with a litreage charge for transport and processing. One kilogram of milk protein is worth 2.5 times more than 1 kilogram of milk fat with a litreage charge of 2.5 cents. Using this payment system, milk supplied from 301 to 670 DIM would receive an average 15 to $20 \%$ more for each liter than milk supplied up to 300 DIM. Turner et al. (2008) used data from Kolver et al. (2008) to show that milk from extended lactations improved dairy product mix and consequently overall milk value $(\$ / L)$ for dairy manufacturers in favor of casein, butter, and cheese production, but not for whole milk powder and skim milk powder.

\section{TMR System}

Kolver et al. (2002) offered both genotypes a TMR diet and achieved a 300-d milk solids yield of $720 \mathrm{~kg} /$ cow for Holstein-Friesian cows (>88\% Northern Hemisphere genes) and $602 \mathrm{~kg} /$ cow for NZ Holstein-Friesian cows $(<12.5 \%$ Northern Hemisphere genes). In the present study the full TMR 670 group had an intermediate level of Northern Hemisphere genes (64\%) and achieved a 300-d milk solids yield of $688 \mathrm{~kg} /$ cow, despite the lameness incurred by one-third of the cows in this group in early lactation. The lameness did not appear to have a major effect on the performance of the cows on the TMR system because the average DIM were similar for the lame cows and the remainder of the cows in the full TMR 670 group (577 and $575 \mathrm{~d}$ ), and the average milk solids yield over the extended lactation for the lame cows was slightly higher than for the remainder of the cows in the group (1,054 vs. $1,036 \mathrm{~kg})$. The similar production levels achieved in the present study and by Kolver et al. (2002) indicate that the TMR diets in the 2 studies were of similar quality for milk solids production. The Northern Hemisphere Holstein cows used by Kolver et al. (2002) were characterized by a high 300-d milk yield and a low fat percentage $(10,097$ $\mathrm{kg} / \mathrm{cow}$ and $3.62 \%$ fat) reflecting the greater emphasis in the Northern Hemisphere on breeding for milk yield (Roche et al., 2006). In contrast, the cows in the present study were bred for milk solids yield as reflected in the lower 300-d milk yield and higher fat percentage $(8,613 \mathrm{~kg} / \mathrm{cow}$ and $4.48 \%$ fat $)$. This could indicate some genetic differences when compared with the cows used by Kolver et al. (2002).

There was greater variation in the performance of cows in the TMR group compared with the pasturebased groups (control 670 and high 670). This was reflected in the higher SE for their milk and milk component data from 301 to 670 DIM (Table 3). Kolver et al. (2002) noted that differences in efficiency ( $\mathrm{kg}$ of milk solids $/ \mathrm{BW}^{0.75}$ ) in late lactation between $\mathrm{NZ}$ and Northern Hemisphere Holstein-Friesian cows offered a TMR diet were probably due to the greater intake ( $\mathrm{kg}$ of $\mathrm{DMI} / \mathrm{kg}$ of BW expressed as a percentage) of the Northern Hemisphere cows relative to the NZ cows (3.32 vs. $3.04 \%)$. This was taken to indicate the unsuitability, compared with the Northern Hemisphere genotype, of the NZ Holstein-Friesian for the intensive TMR diet. In the present study, the full TMR 670 group had a lower milk solids ratio (annualized/normal) than the groups offered a pasture-based diet (0.74 vs. $>0.90)$. This was probably because of their decline in DMI from 350 DIM, their greater partitioning of feed energy to BW, and that a higher proportion of cows in this group dried off earlier (Table 7). This suggests that although the full TMR 670 group was able to achieve a high milk solids yield by 300 DIM some of these cows were unable to sustain this performance into the extended lactation phase and may be less suited to a TMR diet in this phase. The full TMR group had $64 \%$ Northern Hemisphere genes, but clearly had some metabolic differences, as reflected in lower milk yield, greater milk fat percentage, and a higher propensity to partition feed energy to BW rather than milk production, compared with the cows used by Kolver et al. (2002) that had $>88 \%$ Northern Hemisphere genes. The higher proportion of Northern Hemisphere genes may reflect depressed insulin production and a greater resistance to insulin in the cows containing a higher proportion of Northern Hemisphere genes, which would favor partitioning toward the mammary gland (Roche et al., 2006). This premise was supported by Kay et al. (2007) who collected plasma hormone and metabolite data from wk 1 to 10 on the cows used by Kolver et al. (2008) and found that glucose, insulin, and IGF-1 were negatively correlated with milk solids production in an extended lactation.

Kolver et al. (2008) observed a second lactation peak in the second spring for cows offered pasture-based diets. This was more evident from cows with a high proportion of Northern Hemisphere genes. It was less evident as the level of nutrition increased during the preceding winter feeding period. Our data support these observations for cows offered pasture-based diets, because the increase in milk and milk solids yields for the control 670 and high 670 groups (64\% Northern Hemisphere 
genes) was intermediate between the 2 genotypes that Kolver et al. (2008) used, and appeared to decline as the level of nutrition increased from control to high (e.g., for milk yield, increases of 4.4 and $3.5 \mathrm{~L} / \mathrm{cow}$ ). The higher overall level of nutrition provided by the TMR diet meant that the full TMR 670 group was unable to achieve a second peak in the second spring. Their milk yield declined by $3.7 \mathrm{~L} /$ cow over the same period that the control 670 and high 670 groups increased their milk yield. The second peak achieved by the cows on pasture-based diets simply reflected their improved feeding level in the second spring relative to their feeding level in the preceding winter.

The very high levels of BCS achieved by the full TMR 670 group at the end of their extended lactation would be a management concern, but tended to reflect the low dry-off threshold used in the present study.

\section{Industry Implications}

The Victorian dairy industry has traditionally been based on utilizing pasture grazed in situ and supplemented with grain fed during milking, especially during periods of pasture shortage. This system is most effective when combined with a single concentrated period of calving lasting about $12 \mathrm{wk}$. It can only be sustained if high levels of fertility allow most cows within a herd to conceive during a brief intensive 6 -wk period of AI use. The current project was not able to produce reliable data to allow the fertility of cows undergoing extended lactations to be compared with cows managed under the normal seasonal pattern. Kolver et al. (2008) reported that cows managed under pasture-based conditions as described previously had improved reproductive performance when synchronized and inseminated at about 15 mo postcalving instead of the usual $3 \mathrm{mo}$.

No studies have been conducted on subsequent lactations with cows that have initially had an extended lactation and been managed under pasture-based systems. Osterman and Bertilsson (2003) reported that cows of the Swedish Red and White breed that initially had lactations of 18 mo duration calved in higher body condition and had higher yields in their subsequent lactation. Arbel et al. (2001) noted that when the calving interval of Holstein cows was extended by delaying first insemination date from 93 to $154 \mathrm{~d}$, those cows with extended lactations had a higher BCS as well as higher milk yields in the first $150 \mathrm{~d}$ of their next lactations.

Although there has been a dramatic increase in the number of cows having extended lactations in Victorian dairy herds, the encouraging results obtained from the current trials still need to be incorporated into management systems that continue to allow herd owners to make effective use of pasture-based systems.

\section{CONCLUSIONS}

Improving the level of nutrition for cows undergoing an extended lactation and offered pasture-based or TMR diets improved total lactation performance as expected. However, for cows offered pasture-based diets, it did not improve the performance of cows in the extended lactation phase (post-300 DIM) as measured by the milk solids ratio (annualized/normal) and the percentage of cows milking at drying-off. In contrast, the cows offered the higher quality TMR diet system had a lower milk solids ratio and a lower percentage of cows milking at 600 DIM than cows on pasture-based diets. The control 670 group was on a lower level of nutrition than has been previously studied. There was only a $2.4 \%$ decline in milk solids produced over a 2-yr period compared with that from the control 300 group.

When data from the present study were combined with data from 2 earlier studies on extended lactation the results showed that cows with a high proportion of Northern Hemisphere genes offered pasture-based diets will achieve a high milk solids ratio (annualized/normal), a greater proportion of cows milking at drying-off, and lower BW gain over the lactation. In contrast, improving the overall level of nutrition using pasture-based diets did not result in an improvement in the milk solids ratio or the proportion of cows milking at drying-off. It did lead to an increase in BW gain over the lactation period.

Extended-lactation milk contained greater concentrations of fat and protein than normal lactation milk, which would be a benefit to Victorian dairy farmer in the price received for the milk supplied, and to dairy manufacturers in the dairy product mix and consequently the overall value of the milk $(\$ / \mathrm{kg})$. A TMR diet resulted in a high milk solids yield by 300 DIM for cows containing a moderate level of Northern Hemisphere genes (64\%), but this high performance was not sustainable over the extended lactation period.

\section{ACKNOWLEDGMENTS}

The authors are grateful to D. Mapleson, I. Robinson, R. Case, T. Hookey, and staff at the DPI Ellinbank research farm for technical assistance with cow husbandry, grazing management, and sampling procedures, and to M. Hannah (DPI Ellinbank, Victoria, Australia) for conducting the statistical analyses. This research was funded by the Department of Primary Industries (Victoria), the Geoffrey Gardiner Dairy Foundation Limited (Melbourne, Australia), Keenan Pty. Ltd. (Bendigo, Australia), and the National Herd Improvement Association (Melbourne, Australia). 


\section{REFERENCES}

Arbel, R., Y. Bigun, E. Ezra, H. Sturman, and D. Hojman. 2001. The effect of extended calving intervals in high lactating cows on milk production and profitability. J. Dairy Sci. 84:600-608.

Auldist, M. J., G. O'Brien, D. Cole, K. L. Macmillan, and C. Grainger 2007. Effects of varying lactation length on milk production capacity of cows in pasture-based dairying systems. J. Dairy Sci. 90:3234-3241.

Baird, D. B. 1994. The design of experiments with covariates. $\mathrm{PhD}$ Thesis, University of Otago, New Zealand.

Borman, J. M., K. L. Macmillan, and J. Fahey. 2004. The potential for extended lactations in Victorian dairying: A review. Aust. J. Exp. Agric. 44:507-519.

Collett, D. 1994. Modelling Survival Data in Medical Research. Chapman \& Hall, London, UK.

Dairy Australia. 2006. Situation and Outlook. Online: www. dairyaustralia.com.au Accessed Apr. 10, 2008.

Dillon, P. 1996. Maximising profit in creamery milk production using current research and technology. Ir. Grassl. Anim. Prod. J. 30:821.

Earle, D. F. 1976. A guide to scoring dairy cow condition. J. Agric. 74:228-231.

Genstat. 2007a. The Guide to GenStat: Release 10 - Part 2: Statistics. GenStat Committee. R. W. Payne, ed. VSN International, Hemel Hempstead, UK.

Genstat. 2007b. GenStat Release 10 Reference Manual - Part 3: Procedure Library PL17. R. W. Payne and P. W. Lane, ed. VSN International, Hemel Hempstead, UK.

Kay, J. K., P. W. Aspin, C. V. C. Phyn, J. R. Roche, and E. S. Kolver. 2007. Production and physiological indicators to select cows suitable for extended lactations. Proc. N.Z. Soc. Anim. Prod. $67: 315-319$.

Kolver, E. S., J. R. Roche, C. R. Burke, J. K. Kay, and P. W. Aspin. 2008. Extending lactation in pasture-based dairy cows: 1. Genotype and diet effect on milk and reproduction. J. Dairy Sci. 90:5518-5530.
Kolver, E. S., J. R. Roche, M. J. De Veth, P. L. Thorne, and A. R. Napper. 2002. Total mixed rations versus pasture diets: Evidence for a genotype $\mathrm{x}$ diet interaction in dairy cow performance. Proc. N.Z. Soc. Anim. Prod. 62:246-251.

Lucy, M. C. 2001. Reproductive loss in high producing dairy cattle: Where will it end? J. Dairy Sci. 84:1277-1293.

Malcolm, B. 2005. Economics of extended lactations. Aust. Farm Bus. Mgt. Netwk. J. 2:No. 2.

National Research Council. 1989. Nutrient Requirements of Dairy Cattle. 6th rev. ed. Natl. Acad. Press, Washington, DC.

O'Brien, G. N., and D. J. Cole. 2004. Evaluation of dairy farmer interest in an extended lactation system. Anim. Prod. Aust. $25: 128-131$

Osterman, S., and J. Bertilsson. 2003. Extended calving interval in combination with milking two or three times per day: Effects on milk production and milk composition. Livest. Prod. Sci. 82:139 149.

Roche, J. R., D. P. Berry, and E. S. Kolver. 2006. Holstein-Friesian strain and feed effects on milk production, body weight, and body condition score profiles in grazing dairy cows. J. Dairy Sci 89:3532-3543.

Standing Committee on Agriculture. 1990. Feeding Standards for Australian Livestock: Ruminants. CSIRO Australia, Melbourne, Australia.

Trapnell, L., and B. Malcolm. 2006. Economic analysis of changing from a 300 day lactation to an extended lactation dairy system. Proc. Bienn. Conf. Australas. Farm Bus. Mgt. Netwk., Marcus Oldham College, Geelong, Victoria, Australia.

Turner, S.-A., C. V. C. Phyn, E. S. Kolver, P. W. Aspin, and N Lopez-Villalobos. 2008. Effect of genotype and concentrate supplementation on dairy product mix and the value of milk produced by grazing cows during an extended lactation. Proc. N.Z. Soc. Anim. Prod. 68:79-83.

van Amburgh, M. E., D. M. Galton, D. E. Bauman, and R. W. Everett. 1997. Management and economics of extended calving intervals with use of bovine somatotropin. Livest. Prod. Sci. 50:15-28 